ний і лінгвоаксіологічний виміри» є самостійним, логічно структурованим, цілісним і завершеним дослідженням, виконаним на високому фаховому рівні. Вона характеризується легкістю викладу й стилістичною досконалістю. Працю слід усіляко вітати, - адже вона належить до мовознавчих досліджень, заснованих на міждисциплінарному синтезі лінгвістичних, психологічних, філософських, етичних, культурологічних та інших знань.

\title{
В. Ярмак
}

Інститут мовознавства ім. О. О. Потебні НАН України

м. Київ, Україна

Електронна пошта: veronikaarmak1@gmail.com

https://orcid.org/0000-0002-5670-4440

\section{Yarmak}

O.O. Potebnia institute of Linguistics NAS of Ukraine

Kyiv, Ukraine

E-mail: veronikaarmak1@gmail.com

https://orcid.org/0000-0002-5670-4440

Nikolaienko L. I.

THE REPRESENTATION OF THE EMOTIONS OF ENVY AND COMPASSION IN THE POLISH, RUSSIAN AND UKRAINIAN LANGUAGES: SEMANTIC-COGNITIVE AND LINGUOAXIOLOGICAL ASPECTS

Kyiv : Vydavnychyi dim Dmytra Buraho, 2021. 412 p.

Дата надходження до редакції - 13.10.2021

Дата затвердження редакцією - 18.10.2021

DOI 10.33190/0027-2833-321-2021-6-008

\section{Яремко Я., Лужецька Н.}

\section{ІВАН ФРАНКО І ПОСТУП НОВІТНЬОЇ ЛІНГВІСТИКИ}

Львів : Апріорі, 2021. 432 с.

Цьогоріч лінгвістичне франкознавство збагатилося новим вагомим дослідженням. Це монографія доктора філологічних наук, професора Дрогобицького державного педагогічного університету імені Івана Франка Ярослава Яремка та кандидата філологічних наук, доцента цього ж університету Наталії Лужецької «Іван Франко і поступ новітньої лінгвістики», яка побачила світ у львівському видавництві «Апріорі».

Попри те що термінологічна проблематика у мовній картині світу Івана Франка була й залишається в полі зору численних науковців, вона потребує щоразу нових підходів до вивчення, зокрема, у контексті лінгвокогнітологічної парадигми. У цьому й полягає новаторство рецензованої праці.

Лінгвокогнітологічні ідеї Івана Франка, на думку авторів, створили методологічні підвалини українського антропологічного термінознавства та $€$ об’єктом пропонованого дослідження. Як стверджують науковці, «комплексна характеристика термінів-політонімів <..> у націософському дискурсі 
Івана Франка потребує спостережень не лише за їхнім лексикографічним значенням, а й за прагматичним наповненням» (с. 9).

Монографія складається з чотирьох розділів. У першому, ключовому розділі - «Теоретико-методологічні засади I. Франка як термінознавця і термінотворця: міждисциплінарний вимір» (с. 18-95) - висвітлено модерні, за своєю суттю когнітологічні ідеї митця-вченого, які, на думку дослідників, на століття випередили тогочасну українську (і не тільки) мовознавчу думку та створили методологічне підгрунтя для постання новітніх міждисциплінарних наук - української когнітивної лінгвістики, психолінгвістики, лінгвополітології, теорії комунікації. Лінгвістичне новаторство пульсує у тих питаннях мислителя-науковця, які є актуальними для антропоцентричної НАВІЩО/ЧОМУ-лінгвістики, а саме: «як много важить слово»; що $є$ «змістом нашого внутрішнього "я"»; «нашого внутрішнього, немовби з нами народженого світу, - відбиттям нашої думки», або ж, як сказали б сучасні когнітологи, національної ментальності; чому «плекання мови» є важливим «політичним чинником» (неполітична культура — ce contradictio in adjecto «внутрішня суперечність»); який зв'язок між «духовним обличчям», «духовою фізіономією», «складом душі» та мовою; яка роль «закону непропащої сили» у взаємодії мисленнєвих і комунікативних чинників у процесі себе- і світопізнання; що таке «подвійна свідомість»; почасти, в чому полягає «велика ресорпційна сила нижньої свідомості»; чому «знання предавнє відчути треба, серцем зрозуміть»; які суспільно-психологічні витоки «язикового роздвоєння» - «глибокий психологічний проблем, якого коріння сягає малодосліджених досі тайників...»; чому «те роздвоєння мститься»; як взаємодіють «закони асоціації ідей» і «духова діяльність людська» (с. 44-45) та багато ін.

Зреалізований у монографії когнітивно-дискурсний аналіз Франкового тексту (наукового, публіцистичного, художнього, епістолярного) уможливив актуалізацію відповідей ученого-енциклопедиста на поставлені ним же питання. Як питання, так і відповіді дають підстави авторам рецензованого дослідження кваліфікувати лінгвістичне (міждисциплінарне) новаторство I. Франка як квінтесенцію сучасного антропологічного термінознавства.

За спостереженням Я. Яремка та Н. Лужецької, Іван Франко наповнював новими поняттями і їх носіями - термінами - не лише мовознавство, літературознавство, історію, а й так звані неканонічні науки - філософію, психологію, політологію тощо. І цей процес термінотворення вкорінений у площину міждисциплінарної (антропоцентричної) тріади «культура - свідомість - мовлення». Адже письменник наголошував на важливості рідної мови для духовного становлення людини.

Цікавим є той факт, що автори монографії простежують світоглядну еволюцію I. Франка, яка пов'язана з пошуком мовної самоідентифікації як дороги до себе, до національного «Я». Політика бездержавності позначилася на суспільному мисленні українців та істотно ускладнила соціолінгвістичну ситуацію кінця XIX ст. Тож надзавдання письменника полягало в тому, щоб рідну мову, яка навіть у візії українофілів (М. Костомарова, М. Драгоманова) призначена тільки для «домашнього обихода», перетворити у поліфункціональну - інтелектуально самодостатню, суспільно престижну, ментально націєтворчу.

Як переконливо стверджують автори рецензованої праці, теоретико-методологічні засади мовознавця-новатора, втілені у його термінологічній практиці, стали стратегічним дороговказом для подальшої розбудови української літературної мови, щоб освоювати, за Франком, не лише «нові поля 
невідомих досі понять» ${ }^{1}$, а й «присвоювати нашому народові культурні здобутки інших народів і знайомити інших з його життям»² .

Тому цілком слушним і логічно вмотивованим є другий розділ монографії - «Іван Франко та проблема модернізації українського мовно-культурного простору кінця XIX - початку XX ст.» (с. 96-139). Тут ідеться про Франка-енциклопедиста, Франка-інтелектуала, який формує мовну особистість нового типу — національно гідну і культурно соборну. Ідеал національної самостійності мислитель сприймає в органічному зв'язку з національною мовною особистістю, яка викристалізовується завдяки націософському мисленню, а отже, й політичній картині світу.

Тут вартими уваги є погляди I. Франка щодо відповідності політичних термінів політичним реаліям (а така невідповідність між дефініцією і реалією - доволі поширене явище).

У третьому розділі - «Політична термінолексика Івана Франка як репрезентація новітнього політичного знання» (с. 140-232) - увага закцентована на тематичній стратифікації Франкового лексикону, на джерелах і шляхах формування політичного словника автора (лексикографічний аспект).

Суттєво важливим є підрозділ «Імпліцитні текстові засоби в націософських працях Івана Франка» (с. 218-232). Автори монографії аналізують політичний дискурс письменника 3 погляду лінгвістики та культурології (що, зрештою, простежуємо і в інших розділах дослідження). Серед текстових засобів імпліцитності виокремлено пресупозиції та імплікації, натомість підтекстові засоби формують іронічні та саркастичні натяки, що є невід’ємною рисою ідіостилю письменника.

Найбільшим за обсягом є четвертий розділ монографії «Пізнаючи Франкову концептосферу...» (с. 233-368), який вартий особливої уваги і може, на наш погляд, бути видрукуваний як окрема наукова розвідка. Дослідники не оминають дискусійного питання щодо тлумачення концепту, його структурної і змістової моделі, а відтак аналізують цей феномен у візії Івана Франка. Наскрізність використання терміна концепт простежують у різних дискурсах митця - публіцистичному, науковому, художньому, епістолярному. У кожному з них концепт виступає як духовно-культурний орієнтир, що акумулює в собі значення «думка, ідея, погляд». До таких «світоглядних термінів» у лінгвофілософському дискурсі Івана Франка належать концепти «цілий чоловік», народ, нація, поступ, револючіонізм. Апелюючи до етичних ідеалів Івана Франка, його світоглядних устремлінь, дослідники звертають увагу на життєві максими письменника, пов'язані з морально-етичним вибором.

Науковці обгрунтовано доводять, що «завершальним рівнем у структурі комунікативної особистості є трансцендентний. Без цього рівня неможливе творення духовних цінностей» (с. 310). Звідси випливає логічне питання про вивчення не лише мовної (мовленнєвої), а й концептуальної (цілісної) особистості.

Прикметно, що завдяки ретельному контекстуально-інтерпретаційному аналізу різнотипних текстів авторам вдалося простежити надзвичайно тонку межу між терміном і концептом, виявити найделікатніші грані метафоричної трансформації термінів-політонімів, побачити новаторство універсальної термінологічної практики Івана Франка та джерела іiі виникнення.

1 Цит. за: Франко I. Михайло П[етрович] Старицький. Зібрання творів у n'ятдесяти mомах. Т. 33. Київ : Наук. думка, 1982. С. 375.

2 Цит. за: Франко І. Промова на 25-літньому ювілеї. Франко I. Зібрання творів у n'ятдесяти томах. Київ : Наук. думка, 1981. Т. 31. С. 309. 
Відзначимо, що структура монографії добре продумана, розділи взаємодоповнювальні і фахово висвітлені. Однак, на наш погляд, певної уніфікації потребують терміни мовна і мовленнєва особистість (розділ 2, с. 101-102, 104). У четвертому розділі можна було б виокремити концепти воля, духовність, naтріотизм, які б органічно вливалися у надмовний (трансцедентний) вимір людської екзистенції, забезпечуючи її цілісність і довершеність. Але осягнути всесвіт Франкового Слова - завдання не $з$ легких, тому погоджуємося 3 авторським баченням основних маркерів ідіостилю письменника, виокремленням ключових концептів як засобів модерного світо- i смислотворення.

Із певністю можемо стверджувати, що монографія Я. Яремка та Н. Лужецької «Іван Франко і поступ новітньої лінгвістики» заповнила відчутну прогалину у лінгвістичному франкознавстві, стала предтечею якісно іншого, інтерлінгвістичного (лінгвокогнітологічного) вектора аналізу спадщини митця, багатогранно розкрила потенціал Слова, що так «много важить!» і для самого українського Мойсея, і для авторів зокрема. Отже, мовознавцям вдалося оприявнити нові грані «Франка незнаного» (Є. Маланюк).

Дослідження, безперечно, варте уваги науковців, викладачів, аспірантів і студентів та всіх, кого цікавлять проблеми антропологічного термінознавства й лінгвістичної франкіани.

\section{У. Галів}

Дрогобицький державний педагогічний університет імені Івана Франка м.Дрогобич, Україна

Електронна пошта: uliana_mishchyk@ukr.net

https://orcid.org/0000-0002-8511-1484

\section{U. Haliv}

Drohobych Ivan Franko State Pedagogical University

Drohobych, Ukraine

E-mail: uliana_mishchyk@ukr.net

https://orcid.org/0000-0002-8511-1484

\section{Yaremko Ya., Luzhetska N. \\ IVAN FRANKO AND PROGRESS OF MODERN LINGUISTICS}

Lviv : Apriori, 2021. 432 p.

Дата надходження до редакції - 07.10.2021

Дата затвердження редакцією - 13.10.2021 